\title{
Study on Fatigue Strength and Life of Freight Car Frame after Making Holes
}

\author{
Cheng wei ${ }^{1, a}$, Cai kaiwu ${ }^{2}$, Qu fukang ${ }^{1}$ and Xiao jin ${ }^{1}$ \\ ${ }^{1}$ Huali College Guangdong University of Technology, Mechanotronics Department, 511325 Guangzhou, China \\ ${ }^{2}$ Huali College Guangdong University of Technology, Architecture Department, 511325 Guangzhou, China
}

\begin{abstract}
When the chassis of a freight car is reassembled, it is necessary to make holes on the summer beams of the frame. In order to evaluate the effect of making holes on the fatigue strength and life of the whole frame, the stress analysis and life calculation of the freight car frame are carried out under four common working conditions with finite element analysis software based on the finite element theory, combined with the load, fatigue type and frame material parameters of semi-trailer tractor.After analysis, it is found that the stress level of the whole truck frame is below the fatigue limit of the material after making holes of the truck frame, and the life of the strength meets the design requirements of refitting.
\end{abstract}

\section{Introduction}

With the development of highway transportation in China, the improvement design of freight cars is needed in some special industries. When a freight car is designed for improvement, some structural changes need be made to the frame of the freight car: four holes should be drilled independently above the upper and web flanges of the girder, and another support is installed above the web of the girder. At the same time, we have to consider whether the design of the truck frame punching will affect the strength of the improved frame structure[1] .In order to avoid the phenomenon of fatigue and fracture at the at the holes in the punched web flange, it is necessary to analyze the static and dynamic fatigue of the punched frame after installation a support to predict the possibility of the fracture and finally evaluate the fatigue life of the whole frame.

\section{Establishing the geometric model}

The geometric model of the frame can be made with a three-dimensional design software, then it is imported into the large general analysis software of MSC Simxpert. We can see the truck frame model as shown in Figure 1 after connecting the center points at the position of the beam and using the line to indicate the interface properties of the beam unit[2,3].

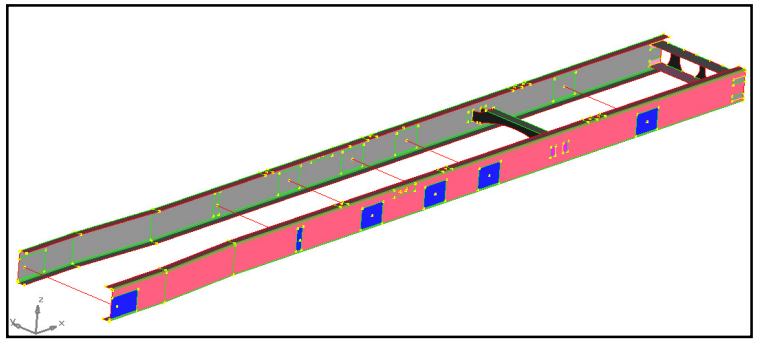

Figure 1. Geometric model of introducing truck frame.

\section{Material and unit cross section properties}

\subsection{Material properties}

The material of the longitudinal beam crossbeam is S420MC, whose elastic modulus is $\mathrm{E}=205 \mathrm{GPa}$ and Poisson's ratio is $\mathrm{u}=0.29$. According to this parameter, the S-N curve of the material is obtained by software MSC.fatigue, as shown in Figure 2.

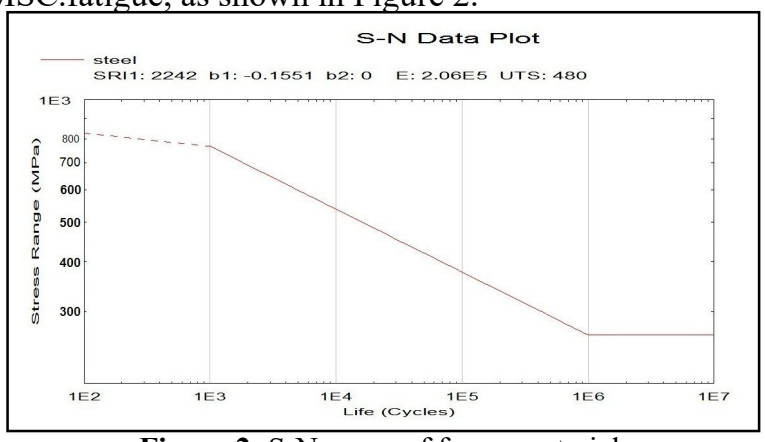

Figure 2. S-N curve of frame material. 


\subsection{Element cross section properties}

The finite element model of the whole truck frame is divided into 13 components, in which 8 beams are connected to the longitudinal beam through the flange form, and the main frame structure is formed. The crossbeam is named $\mathrm{H} 1, \mathrm{H} 2$, and $\mathrm{H} 3$ once in the past. $\mathrm{H} 8$, in addition to $\mathrm{H} 6$ and $\mathrm{H} 8$, are cylindrical and longitudinal beams connected by connecting flanges and bolts[4]. The sectional properties of each component unit of the truck frame are shown in Table 1.

Table 1. Element section properties.

\begin{tabular}{|c|c|c|c|c|}
\hline Parts & Cell attribute & Dimension & Drder & Constant \\
\hline Longitudinal beam & Shell & $10 \mathrm{~mm}$ & 2 & Thickness $7 \mathrm{~mm}$ \\
\hline CrossbeamHl & Beam & $300 \mathrm{~mm}$ & 1 & $\begin{array}{c}\text { External diameter } \\
90 \mathrm{~mm} \\
\text { Internal diameter } 50 \mathrm{~mm}\end{array}$ \\
\hline CrossbeamH2 & Beam & $300 \mathrm{~mm}$ & 1 & $\begin{array}{l}\text { External diameter } 90 \mathrm{~mm} \\
\text { Internal diameter } 50 \mathrm{~mm}\end{array}$ \\
\hline CrossbeamH3 & Beam & $300 \mathrm{~mm}$ & 1 & $\begin{array}{l}\text { External diameter } 90 \mathrm{~mm} \\
\text { Internal diameter } 50 \mathrm{~mm}\end{array}$ \\
\hline CrossbeamH4 & Beam & $300 \mathrm{~mm}$ & 1 & $\begin{array}{l}\text { External diameter } 90 \mathrm{~mm} \\
\text { Internal diameter } 50 \mathrm{~mm}\end{array}$ \\
\hline CrossbeamH5 & Beam & $300 \mathrm{~mm}$ & 1 & $\begin{array}{l}\text { External diameter } 90 \mathrm{~mm} \\
\text { Internal diameter } 50 \mathrm{~mm}\end{array}$ \\
\hline CrossbeamH6 & Shell & $10 \mathrm{~mm}$ & 2 & Thickness $5 \mathrm{~mm}$ \\
\hline CrossbeamH7 & Beam & $300 \mathrm{~mm}$ & 1 & $\begin{array}{l}\text { External diameter } 90 \mathrm{~mm} \\
\text { Internal diameter } 50 \mathrm{~mm}\end{array}$ \\
\hline CrossbeamH8 & Shell & $10 \mathrm{~mm}$ & 2 & Thickness $5 \mathrm{~mm}$ \\
\hline Connection flange & Shell & $10 \mathrm{~mm}$ & 2 & Thickness $12 \mathrm{~mm}$ \\
\hline Front bolster & Spring & $40 \mathrm{~mm}$ & ----- & $280 \mathrm{e} 3 \mathrm{~N} / \mathrm{M}$ \\
\hline Back bolster & Spring & $40 \mathrm{~mm}$ & ----- & $412.5 \mathrm{e} 3 \mathrm{~N} / \mathrm{M}$ \\
\hline
\end{tabular}

\subsection{Load and boundary condition}

Because the load of the frame is extremely complex during the working process, it is impossible for us to obtain the actual road load form of the vehicle. Here we mainly consider the following two static loads and boundary conditions such as table 2 .

Table 2. Load and boundary conditions.

\begin{tabular}{|c|c|c|}
\hline Condition & Load & Boundary condition \\
\hline \multirow{3}{*}{ Bending } & $\begin{array}{c}\text { Load of objects and carriage: } 98000 \mathrm{~N}, \\
\text { Load of motor and gear box:11600N, } \\
\text { Load of dricab and driver:4950N, } \\
\text { Dynamic load coefficient: } \mathrm{K}=1, \\
\text { Load direction }(0,0,-1)\end{array}$ & $\begin{array}{c}\text { Lower node of the leaf spring is fixed, } \\
\mathrm{X}, \mathrm{Y} \text { upper node and degree of turning } \\
\text { freedom of the back leaf spring is restrained, } \\
\mathrm{Z} \text { direction of the leaf spring is sustained }\end{array}$ \\
\hline Braking & $\begin{array}{c}\text { Load of objects and carriage: } 98000 \mathrm{~N}, \\
\text { Load of motor and gear box:11600N, } \\
\text { Dricab and driver:4950N, } \\
\text { Verticaldynamic load coefficient:K=1, } \\
\text { Longitudinaldynamic load }\end{array}$ & $\begin{array}{c}\text { Lower node of the leaf spring is fixed } \\
\text { Restrain, } \mathrm{X}, \mathrm{Y} \text { upper node and degree of } \\
\text { turning freedom of the back leaf spring } \\
\text { Sustain, }\end{array}$ \\
& $\begin{array}{c}\mathrm{Z} \text { direction of the leaf spring } \\
\text { coefficient:K=1.5,Longitudinalaccelerated speed } \\
\text { is } 0.6 \mathrm{~g}\end{array}$ & \\
\hline
\end{tabular}




\section{Life analysis of the fame}

\subsection{Maximum stress analysis under four conditions}

Through the software calculation and simulation, the maximum stress results of the key parts of the integrated frame structure under four common conditions of bending, torsion, braking and turning can be obtained as follow table 3 .

Table 3. Stress analysis result of frame.

\begin{tabular}{|c|c|c|c|c|}
\hline Condition & $\begin{array}{c}\text { Original } \\
\text { position }\end{array}$ & $\begin{array}{c}\text { Web } \\
\text { hole } \\
\text { position }\end{array}$ & $\begin{array}{c}\text { Flange } \\
\text { hole } \\
\text { position }\end{array}$ & $\begin{array}{c}\text { Maxim } \\
\text { um } \\
\text { stress }\end{array}$ \\
\hline Bending & $\begin{array}{c}237.6 \\
\mathrm{MPa}\end{array}$ & $\begin{array}{c}291.1 \\
\mathrm{MPa}\end{array}$ & $\begin{array}{c}322.7 \\
\mathrm{MPa}\end{array}$ & $\begin{array}{c}322.7 \\
\mathrm{MPa}\end{array}$ \\
\hline Torsion & 129.9 & 113.8 & 155.9 & $\begin{array}{c}155.9 \\
\mathrm{MPa}\end{array}$ \\
\hline Braking & $\mathrm{MPa}$ & $\mathrm{MPa}$ & $\mathrm{MPa}$ \\
\hline Turning & 330.9 & $\begin{array}{c}147.6 \mathrm{MP} \\
\mathrm{a}\end{array}$ & $\begin{array}{c}167.2 \\
\mathrm{MPa}\end{array}$ & $\begin{array}{c}167.2 \\
\mathrm{MPa}\end{array}$ \\
\hline & $\mathrm{MPa}$ & $\mathrm{MPa}$ & $\begin{array}{c}264.8 \\
\mathrm{MPa}\end{array}$ & $\begin{array}{c}330.9 \\
\mathrm{MPa}\end{array}$ \\
\hline
\end{tabular}

Under bending condition, the frame is running on a straight road, and the dynamic load factor is 1.8 . The turning condition is first to apply the longitudinal acceleration $0.6 \mathrm{~g}$, and then consider the influence of the dynamic load: the vertical dynamic load coefficient is 1 , the longitudinal 1.5. In the same way, the turning condition is based on the lateral $0.6 \mathrm{~g}$ acceleration, and the lateral dynamic load coefficient 1.4 is considered[5]. Due to the stress concentration at the edge of the hole, the stress at the hole is greater.

\subsection{Life calculation}

When studying the life of the frame, the maximum stress of the whole frame is taken as the basis. According to table 4-1, the maximum stress value of the frame under the four working conditions are different. The calculated loads under various working conditions exceed the general standard requirements. According to the average stress calculated by the above dynamic load coefficient and load, the life of the frame under the corresponding working conditions is calculated.

In order to consider the influence degree of the perforation on the web of the frame, by calculating the maximum stress $\mathrm{S} 2=175 \mathrm{MPa}$ of the edge of the web under the four working conditions, it can be found that the stress concentration exists in the edge of the web, but the stress value of the web is lower than the fatigue limit of the material after the support is installed.

In order to consider the influence degree of perforation on the upper wing of the frame, the maximum stress $\mathrm{S} 3=227 \mathrm{MPa}$ of the wing hole edge under four working conditions is calculated.

The maximum stress S4=224MPa of the frame under four operating conditions can be found that the maximum stress value of the frame after drilling is basically the stress at the edge of the wing plate, and the life of the frame is largely determined by the stress at the edge of the wing plate[6].

Using the S-N curve of the frame material, the life estimation under the average stress is considered as shown in Figure 3.

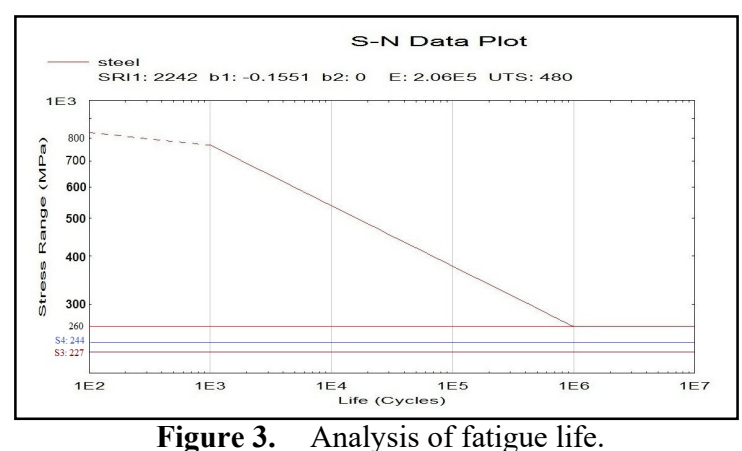

It can be seen from the above picture that the fatigue limit of the frame is $260 \mathrm{MPa}$ according to the frame material, and the maximum stress value S3 of the flange plate on the frame is below the fatigue limit after the frame being punched, and it can be considered safe.

From the above stress mean analysis, the maximum stress value of the whole frame is in the stress concentration area at the edge of the wing plate, but under the given load form, the value is lower than the fatigue limit of the material, which shows that the whole structure meets the design requirements.

\section{Conclusion}

The maximum stress value of the frame after being punched under four static conditions is calculated, and the effect of punching on the fatigue life of the frame is considered, and the maximum stress at the edge of the hole on the frame is calculated. Through analysis, it is found that the maximum stress value at the edge of the hole is larger when the web is punched and installed, and the maximum stress of the whole frame is basically at the edge of the wing plate. Punching on the frame only changes the local stress state and does not affect the stress distribution of the whole structure. After fitting the bracket, the maximum stress is concentrated on the edge of the flange hole, and the influence degree is relatively large. According to the stress-life analysis method, we find that the maximum stress and the hole edge stress of the truck frame after punching and fitting the bracket are lower than the fatigue limit of the material by calculating according to the given load form[7,8]. It can be considered as safe and the punching design meets the requirements of the refit design.

\section{References}

1. S. Changqing, D. Houming, Y. Shengmei. Automobile Technology. 4,7 (2004)

2. Y. Huijun, W Zhilin, S. Zhihui. Journal of Machine Design. 11,27 (2005) 
3. J. Changzhong, W. Pengbo. Computer Aided Engineering.1,57(2013)

4. Z. Yu, C. Ligang, Machinery Design \& Manufactur.6,81(2009)

5. Z. Yunan, S. Lukai. Auto Time. 20,32 (2017)

6. Y. Xianfeng, L. Chongtian, Y. Wubing. Automobile Applied Technology. 3,23 (2018)

7. Y. Jiayin. Industrial Design. 12,16 (2017)

8. P. Yu. Journal of Mechanical Strength. 6,39 (2017) 